\title{
Efek Mediasi Profitabilitas: Modal Intelektual, Diversifikasi Pendapatan, dan Nilai Perusahaan
}

\author{
Windie Yustyarani $i^{1 *}$, Indah Yuliana ${ }^{2}$ \\ 1,2 Universitas Islam Negeri Maulana Malik Ibrahim Malang \\ 1'wyustyarani@gmail.com, 2indahoty@manajemen.uin-malang.ac.id \\ *Penulis Korespondensi
}

\begin{abstract}
This study aims to examine and analyze the effect of intellectual capital and income diversification on firm value mediated by profitability. This study uses secondary data from annual reports on banks listed on the Indonesia Stock Exchange in 2013-2018. There are 30 banking samples in this study based on established criteria (purposive sampling). Data analysis using the WarpPLS 6.0 program. The results shows that intellectual capital had a positive effect on profitability and on company value, income diversification had a negative effect on profitability, while it was found to have no effect on company value, profitability had a positive effect on company value, intellectual capital had an indirect effect on firm value mediated by profitabilit with partial mediation, while mediation is not supported by the indirect effect of Diversification of Revenue on Company Value.
\end{abstract}

Keywords: Bank; Intellectual Capital; Income Diversification; Profitability; Value

\begin{abstract}
Abstrak
Penelitian ini bertujuan untuk menguji dan menganalisis pengaruh modal intelektual dan diversifikasi pendapatan terhadap nilai perusahaan dengan dimediasi oleh profitabilitas. Penelitian ini menggunakan data sekunder laporan tahunan pada perbankan yang terdaftar di BEI tahun 2013-2018. Terdapat 30 perbankan menjadi sampel dalam penelitian ini berdasarkan kriteria yang ditetapkan (purposive sampling). Analisis data menggunakan program WarpPLS 6.0. Hasil penelitian menunjukkan bahwa Modal intelektual berpengaruh positif terhadap Profitabilitas maupun terhadap Nilai Perusahaan, Diversifikasi Pendapatan berpengaruh negatif terhadap Profitabilitas, sedangkan ditemukan tidak berpengaruh terhadap Nilai Perusahaan, Profitabilitas berpengaruh positif terhadap Nilai Perusahaan, Modal Intelektual berpengaruh secara tidak langsung terhadap Nilai Perusahaan dimediasi oleh Profitabilitas secara parsial (partial mediation), sedangkan mediasi tidak didukung pada pengaruh tidak langsung Diversifikasi Pendapatan terhadap Nilai Perusahaan.
\end{abstract}

Kata kunci: Bank; Modal Intelektual; Diversifikasi Pendapatan; Profitabilitas; Nilai

\section{Cara Mengutip:}

Yustyarani, W. Yuliana, I. (2020). Efek Mediasi Profitabilitas: Modal Intelektual, Diversifikasi Pendapatan, dan Nilai Perusahaan. Esensi: Jurnal Bisnis dan Manajemen. Vol. 10 (1) : 83-94. DOI: http://doi.org/10.15408/ ess.v10i1.15564 


\section{PENDAHULUAN}

Perbankan memiliki kontribusi cukup besar pada pendapatan negara dengan fungsinya sebagai lembaga Financial Intermediary, yakni perantara antara pihak pengguna dana dan pemilik dana (Arief \& Yahya, 2014). Berdasarkan laporan perekonomian Indonesia tahun 2018 sekitar 70 persen pembiayaan ekonomi bersumber dari kredit perbankan. Perbankan sebagai sebuah perusahaan tentu memiliki tujuan dari operasional yang telah dilakukan. Theory of the firm menyiratkan bahwa mengoptimalkan kekayaan atau nilai perusahaan serta kemakmuran para pemegang saham merupakan tujuan perusahaan yang utama (Salvatore, 2005).

Nilai perusahaan (firm value) merupakan interpretasi kesejahteraan pemegang saham atas dasar harga sahamnya. Semakin tingginya harga saham suatu perusahaan dari nilai bukunya menunjukkan semakin tingginya kesejahteraan pemegang, maupun sebaliknya nilai harga saham yang semakin rendah dari nilai bukunya menunjukkan semakin rendah kesejahteraan pemegang saham menurut Handoko dalam (Arief \& Yahya, 2014). Harga saham perbankan di Indonesia yang salah satunya dicerminkan oleh indeks infobank15, yaitu indeks yang mengukur kinerja harga saham dari 15 perbankan dengan likuiditas perdagangan yang tinggi dan faktor fundamental yang baik. Indeks harga saham infobank15 tahun 2017-2019 mengalami kenaikan, namun pada januari dan februari tahun 2020 harga saham perbankan mengalami penurunan sekitar 27 rupiah pada bulan januari dan sekita 44 rupiah pada bulan februari 2020 untuk harga penutupan setiap lembar sahamnya, dimana indeks harga lainnya juga cenderung mengalami penurunan.

Terdapat 3 faktor yang bisa berpengaruh untuk meningkatkan nilai perusahaan, yaitu: (a) baiknya tata kelola perusahaan, (b) kemampuan menghasilkan laba, (c) investor umumnya menghindari risiko (Sudana, 2009). Kemampun perusahaan menghasilkan laba dapat dilihat dari rasio profitabilitas. Dalam meningkatkan profitabilitas, sumber daya perusahaan dioptimalkan untuk menghasilkan laba, baik melalui kegiatan operasional maupun investasi dengan penciptaan nilai tambah (value added).

Proses bisnis telah mengalami perkembangan seiring dengan perkembangan teknologi dan ilmu pengetahuan. Proses bisnis yang sebelumnya didasarkan atas tenaga (labor based business) juga berkembang menjadi bisnis didasarkan atas pengetahuan (knowledge based business), sehingga karakteristik utama perusahaan merupakan perusahaan berdasarkan pengetahuan (Sawarjuwono \& Kadir, 2003). Menurut Petty dan Guthrie dalam (Subkhan \& Citraningrum, 2010) Modal Intelektual merupakan salah satu pendekatan dalam pengukuran dan penilaian aset tidak berwujud. Modal Intelektual dianggap bisa memiliki peran dalam meningkatkan nilai perusahaan ataupun kinerja keuangan. Tingginya nilai modal intelektual (VAIC ${ }^{\mathrm{TM}}$ ) menunjukkan efisiensi pemanfaatan modal perusahaan, sehingga menciptakan value added bagi perusahaan (Sunarsih, Made, \& Mendra, 2012). Pemanfaatan Modal Intelektual secara efisien akan meningkatkan nilai pasar perusahaan (Hadiwijaya \& Rohman, 2013). Nilai tersembunyi yang berasal dari selisih antara harga saham dan nilai bukunya diyakini sebagai modal intelektual yang dihargai dan diakui oleh pasar. 
Kemudian dalam peningkatan profitabilitas dapat dilakukan dengan strategi diversifikasi yang dapat dilakukan pada aset maupun pendapatan perusahaan. Diversifikasi merupakan strategi perusahaan dengan tujuan untuk meningkatkan profitabilitas dengan cara meningkatkan volume penjualan melaui bentuk produk atau pasar baru (Sari, Wiratno, \& Suyono, 2014). Diversifikasi pendapatan merupakan strategi bank dalam memperoleh pendapatan yang tidak hanya dari satu sumber namun beberapa sumber. Pendapatan bunga merupakan pendapatan utama perbankan dari aktivitas tradisional yaitu penyaluran kredit, sementara itu dalam diversifikasi pendaptan perbankan mencari sumber pendapatan baru lainnya yang diharapkan lebih stabil yaitu pendapatan non bunga (non interest income) (Widiasari \& Pangestuti, 2015). Dalam 7 tahun terakhir (2013-2017) berdasarkan laporan statistik perbankan, pendapatan perbankan masih didominasi oleh pendapatan bunga bank dengan rata-rata 73 persen dari total pendapatan bank.

Secara empiris Modal Intelektual (IC) memiliki pengaruh positif terhadap Return on Assets (ROA) (Alipour, 2012; Octavio \& Soesetio, 2019; Tran \& Hong Vo, 2018) maupun terhadap Return on Equity (ROE) (Buallay, 2019; Wijayani, 2017). Penelitian pada bank konvensional dan bank syariah juga dilakukan dengan hasil IC berpengaruh terhadap ROE hanya pada bank syariah, sedangkan IC berpengaruh terhadap ROA dan ROE pada bank konvensional (Buallay, 2019). Sementara itu, hasil berbeda pada penelitian (Aida \& Rahmawati, 2015) bahwa Modal Intelektual ditemukan tidak memiliki pengaruh terhadap ROE. Kemudian Penelitian terkait Modal Intelektual dan Nilai Perusahaan juga dilakukan sebelumnya oleh beberapa peneliti. (Arief \& Yahya, 2014; Putra, 2012; Sudibya \& Restuti, 2014) menemukan Modal Intelektual memiliki pengaruh positif terhadap PBV. Sementara hasil penelitian (Aida \& Rahmawati, 2015; Hadiwijaya \& Rohman, 2013; Werastuti, 2014) Modal Intelektual tidak berpengaruh signifikan terhadap nilai perusahaan. (Lestari, 2017) menemukan Modal Intelektual memiliki pengaruh negatif terhadap PBV. Berdasarkan hasil penelitian (Arief \& Yahya, 2014; Hadiwijaya \& Rohman, 2013) Modal Intelektual secara tidak langsung memiliki pengaruh terhadap Nilai Perusahaan, yakni melalui rasio profitabilitas yang diproksikan Return on Assets (ROA) ataupun Return on Equity (ROE) yang memdiasi hubungan keduanya (Sudibya \& Restuti, 2014) meskipun pengaruhnya tidak lebih kuat dari pengaruh langsungnya.

Penelitian (Sianipar, 2015) menemukan hasil bahwa Diversifikasi Pendapatan secara positif berpengaruh terhadap Return on Assets (ROA). Bukan hanya pada pengembalian aset, pengaruh Diversifikasi Pendapatan terhadap dua proksi profitabilitas yakni ROA dan ROE ditemukan memiliki hasil positif (Luu, Nguyen, Vu, \& Tuan, 2019; Setiawan \& Pramika, 2019; Sharma \& Anand, 2018). Berbeda dengan (Hafidiyah \& Trinugroho, 2016) hasilnya menunjukkan bahwa pengaruh Diversifikasi Pendapatan terhadap ROA dan ROE yaitu negatif (Turkmen \& Yigit, 2012).

Diversifikasi pendapatan secara positif berpengaruh terhadap nilai perusahaan yang diukur dengan nilai Tobin's Q (Lukmawijaya \& Suk, 2015) Sebaliknya penelitian tersebut tidak dukung oleh hasil penelitian (Aprilia \& Darmawan, 2019; Natalia, Kurniawan, \& Firsty, 2016; Sianipar, 2015) yang hasilnya menunjukkan bahwa Diversifikasi Pendapatan 
Tidak berpengaruh signifikan terhadap Nilai Perusahaan. (Aprilia \& Darmawan, 2019; Hasibuan, Ar, \& Endang, 2016; Simetris \& Darmawan, 2019) menemukan bahwa Return on Equity (ROE) berpengaruh positif terhadap nilai perusahaan. Namun berbeda dengan hasil penelitian (Cahya \& Riwoe, 2018) ROE berpengaruh negatif terhadap nilai perusahaan, namun Return on Assets (ROA) berpengaruh positif terhadap nilai perusahaan. (Murni \& Sabijono, 2018) menemukan bahwa ROE tidak bepengaruh signifikan terhadap nilai perusahaan.

Beberapa hasil penelitian sebelumnya menunjukan inkonsistensi hasil sehingga perlu dilakukan penelitian lebih lanjut. Penelitian ini akan menganalisis Modal Intelektual dan Diversifikasi Pendapatan terhadap Nilai Perusahaan dengan Profitabilitas sebagai variabel intervening. Penggunaan Diversifikasi Pendapatan pada variabel independen serta penggunaan dua proksi dalam pengukuran profitabilitas yakni ROA dan ROE yang tidak dilakukan pada penelitian-penelitian sebelumnya.

\section{METODE}

Penelitian ini merupakan penelitian kuantitatif dengan pengujian hipotesis menggunakan software Warp PLS 6.0. Populasi dalam penelitian ini adalah seluruh perbankan yang terdaftar di Bursa Efek Indonesia (BEI) periode tahun 2013-2018 yang berjumlah 45 perbankan. Sementara pengambilan sampel didasarkan atas kriteria tertentu (purposive sampling) sehingga didapatkan 30 perbankan sebagai sampel penelitian. Sumber data berupa data sekunder yang dikumpulan dari laporan tahunan perusahaan melalui situs resmi BEI (www.idx.co.id), website perusahaan serta harga saham penutupan melalui website www.duniainvestasi.com/bei/. Adapun variabel yang digunakan yaitu Modal Intelektual dan Diversifikasi Pendapatan sebagai variabel independen, Nilai Perusahaan sebagai variabel dependen serta profitabilitas sebagai variabel mediasi (intervening).

Analisis data dalam penelitian ini dilakukan terdiri dari analisis statistik deskriptif, evaluasi model pengukuran (outer model), evaluasi model struktural (Goodness of Fit/ inner model) serta uji mediasi dengan alat analisis jalur (path analysis) menggunakan software Warp PLS 6.0. Analisis jalur (path analysis) untuk menguji hubungan lansung maupun tidak langsung dari variabel bebas dan variabel terikat yang diteliti.

\section{HASIL DAN PEMBAHASAN}

Analisis variabel pada penelitian ini dimulai dengan analisis deskriptif yang terlihat pada Tabel 1 berikut: 
Tabel 1. Statistik Deskriptif

\begin{tabular}{lccccc}
\hline \multicolumn{1}{c}{ Variabel } & Obs & Min & Max & Mean & Std. Dev \\
\hline Modal Intelektual (IC) & 180 & 0,996 & 8,903 & 2,992 & 1,135 \\
Diversifikasi Pendapatan (ID) & 180 & 0,034 & 1,163 & 0,368 & 0,242 \\
ROA & 180 & 0,001 & 0,054 & 0,019 & 0,011 \\
ROE & 180 & 0,010 & 0,341 & 0,112 & 0,071 \\
Nilai Perusahaan & 180 & 0,142 & 9,809 & 1,557 & 1,137 \\
\hline
\end{tabular}

Sumber: data diolah (2020)

Tabel 1 menunjukkan bahwa dalam penelitian ini terdapat total 180 pengamatan, yaitu pada 30 perbankan yang tedaftar di BEI dengan periode 2013-2018 (6 tahun). Nilai minimum modal intelektual pada DNAR tahun 2018 sebesar 0,996. Sementara nilai maksimum sebesar 8,903 pada SDRA 2014 dengan nilai rata-rata modal intelektual sebesar 2,992. Modal intelektual mencerminkan kemampuan mengelola potensi yang ada dalam menciptakan valu added. Nilai minimum variabel diversifikasi pendapatan pada MAYA 2016 sebesar 0,034, nilai maksimum sebesar 1,163 pada BSIM 2016 dengan nilai rata-rata sebesar 0,368. Variabel diversifikasi pendapatan menunjukkan strategi yang dilakukan perbankan dalam memperoleh pendapatan, apakah dengan fokus pada pendapatan bunga ataukah sumber pendapatan non bunga lebih besar yang mencerminkan diversifikasi pendapatan.

Profitabilitas pada proksi ROA memiliki nilai minimum sebesar 0,001 pada BBKP tahun 2017 dan nilai maksimum sebesar 0,054 pada BBMD 2013 dengan nilai ratarata 0,019. Sementara itu profitabilitas yang diukur dengan proksi ROE memiliki nilai minimum pada BINA 2018 sebesar 0,010, nilai maksimum sebesar 0,341 pada BBRI tahun 2013 dengan nilai rata-rata ROE sebesar 0,112. Profitabilitas mencerminkan kemampuan dalam menghasilkan laba yang berasal dari aktiva maupun ekuitas yang dimiliki. Nilai minimum variabel nilai perusahaan yang diukur dengan PBV sebesar 0,142 pada BJBR tahun 2018, nilai maksimum pada BBRI tahun 2016 sebesar 9,809 dengan nilai rata-rata 1,557. Adapun nilai perusahaan dapat menggambarkan besarnya penilain pasar pada perusahaan dimana harga saham dibandingkan dengan nilai buku saham perusahaan.

Tabel 2. Hasil Outer Model

\begin{tabular}{ccc}
\hline Variabel & P value & Comp. Reliab. dan Cronbach's alpha \\
\hline IC & $<0,001$ & 1,000 \\
ID & $<0,001$ & 1,000 \\
Profitabilitas & $<0,001$ & 1,000 \\
PBV & $<0,001$ & 1,000 \\
\hline
\end{tabular}

Sumber: data diolah (2020) 
Tabel 2 menunjukkan hasil evaluasi model pengukuran (outer model), dimana evaluasi ini dilakukan dengan melihat validitas dan reliabilitas dari variabel dan indikatornya. Menurut (Sholihin \& Ratmono, 2013: 65) terdapat salah satu syarat Convergent Validaty untuk konstruk reflektif, yaitu nilai $\mathrm{p}$ signifikansi $\mathrm{p}<0,05$. Adapun hasil di atas menunjukkan nilai $\mathrm{p}$ value untuk masing-masing variabel bernilai $<0,001$ sehingga Convergent Validaty terpenuhi dan dikatakan valid. Kemudian nilai composite reliability dan cronbach's alpha $>$ 0,70 maka dapat dikatakan reliable (Sholihin \& Ratmono, 2013: 73). Tabel di atas menunjukkan nilai composite reliability dan cronbach's alpha untuk setiap variabel sebesar 1,000, maka dikatakan reliabel.

Tabel 3. Model Fit

\begin{tabular}{lll}
\hline Indeks & & P value \\
\hline Average path coefficient (APC) & 0,275 & $<0,001$ \\
Average R-squared (ARS) & 0,354 & $<0,001$ \\
AVIF & 1,170 & \\
\hline
\end{tabular}

Sumber: data diolah (2020)

Uji kecocokan model digunakan untuk mengetahui apakah suatu model memiliki kecocokan dengan data dengan terdapat 3 indeks pengujian, yaitu Average Path Coefficient (APC), Average R-Squared (ARS) dimana diterima dengan syarat $p$-value $<0,05$ dan Average Varians Factor (AVIF) lebih kecil dari 5. Tabel 3 menunjukkan APC dan ARS memiliki $p$ value $<0,001$ dan nilai AVIF sebesar 1,170 dimana kurang dari 5, sehingga ketiga indeks diterima.

Tabel 4. Hasil Uji Jalur

\begin{tabular}{lcccc}
\hline & $\beta$ & P value & R-Square & Ket. \\
\hline IC à PROFIT & 0,728 & $<0,001$ & \multirow{2}{*}{0,513} & Hipotesis Diterima \\
ID à PROFIT & $-0,128$ & 0,040 & & Hipotesis Ditolak \\
IC à PBV & 0,365 & $<0,001$ & & Hipotesis Diterima \\
ID à PBV & 0,020 & 0,393 & Hipotesis Ditolak \\
PROFIT à PBV & 0,289 & $<0,001$ & & Hipotesis Diterima \\
IC à PROFIT à PBV & 0,227 & $<0,001$ & \multirow{2}{*}{0,195} & Partial Mediation \\
ID à PROFIT à PBV & $-0,002$ & 0,487 & & Mediasi tidak didukung \\
\hline
\end{tabular}

Sumber: data diolah (2020)

H1a : Modal Intelektual berpengaruh positif terhadap Profitabilitas

H1b : Diversifikasi Pendapatan berpengaruh positif terhadap Profitabilitas

H2a : Modal Intelektual berpengaruh positif terhadap Nilai Perusahaan

H2b : Diversifikasi Pendapatan berpengaruh positif terhadap Nilai Perusahaan

H3 : Profitabilitas berpengaruh positif terhadap Nilai Perusahaan 
H4 : Profitabilitas memediasi hubungan antara Modal Intelektual terhadap Nilai Perusahaan

H5 : Profitabilitas memediasi hubungan antara Diversifikasi Pendapatan terhadap Nilai Perusahaan

Tabel 4 menunjukkan hasil uji hubungan antar variabel yang diteliti. Modal Intelektual (IC) dan Profitabilitas memiliki nilai $p$-value $<0,001$ dengan beta 0,728 maka terlihat secara statistik IC berpengaruh positif terhadap profitabilitas, sehingga H1a diterima. Hal ini mengindikasikan bahwa ketika modal intelektual naik diikuti dengan profitabilitas yang naik maupun sebaliknya. Hasil ini konsisten dengan hasil penelitian (Alipour, 2012; Buallay, 2019; Octavio \& Soesetio, 2019; Tran \& Hong Vo, 2018; Wijayani, 2017). Profitabilitas merupakan hasil dari investasi dalam modal intelektual (Amalia \& Annisa, 2018). Potensi yang dimiliki perusahaan, baik berupa human capital maupun structural capital yang mampu dikelola dengan baik sehingga menciptakan value added bagi perusahaan dapat meningkatkan laba perusahaan, sehingga profitabilitas meningkat. Hubungan selanjutnya antara diversifikasi pendapatan (ID) dan profitabilitas secara statistik menunjukkan nilai beta -0,128 dan $p$-value 0,040 yaitu diversifikasi pendapatan berpengaruh negatif terhadap profitabilitas, sehingga H1b ditolak. Hasil ini mendukung penelitian (Hafidiyah \& Trinugroho, 2016; Turkmen \& Yigit, 2012) dimana ketika diversifikasi pendapatan pada perusahaan meningkat diikuti dengan profitabilitas yang menurun maupun sebaliknya. Hal ini dapat disebabkan karena keuntungan yang didapat dari kegiatan bisnis non bunga tidak dapat menutup pengeluaran yang ditimbulkan dari menurunnya pedapatan bunga bank (Lepetit, Nys, Rous, \& Tarazi, 2008). Ketika tingkat diversifikasi meningkat hal tersebut mengarah pada peningkatan biaya yang dikeluarkan dan mungkin diversifikasi mungkin tidak dikaitkan dengan pengembalian yang lebih tinggi di setiap keadaan (Turkmen \& Yigit, 2012). Diversifikasi pendapatan pada perbankan yang tinggi tercermin pada pendapatan non bunga yang tinggi. Pendapatan tersebut dapat diperoleh dari komisi maupun investasi yang dilakukan, sementara itu investasi tidak selalu menjanjikan adanya imbal hasil yang tinggi dibanding biaya yang telah dikeluarkan sehingga hal tersebut dapat kemungkinan menurunkan profitabilitas perusahaan. Nilai R-square IC dan ID terhadap profitabilitas sebesar 51,3\% menunjukkan pengaruh yang tinggi atau kuat.

Pengaruh modal intelektual terhadap nilai perusahaan secara statistik menunjukkan nilai beta 0,365 dengan $p$-value $<0,001$ menunjukkan pengaruh positif, sehingga $\mathrm{H} 2 \mathrm{a}$ diterima. Hasil ini konsisten dengan penelitian (Arief \& Yahya, 2014; Putra, 2012; Sudibya \& Restuti, 2014) dimana modal intelektual yang meningkat diikuti dengan meningkatkan nilai perusahaan maupun sebaliknya. Pengelolaan potensi yang dimiliki dengan baik atau dengan kata lain modal intelektual yang tinggi dapat meningkatkan value added untuk kemudian menjadi sinyal positif bagi investor yang dapat menciptakan nilai (value creation) bagi perusahaan. Sementara itu secara statistik hubungan diversifikasi pendapatan dan nilai perusahaan memiliki nilai $p$-value 0,393 dengan beta 0,020 menunjukkan tidak adanya pengaruh karena nilai signifikansi lebih dari 0,05 sehingga H2b ditolak. Hasil penelitian ini mendukung penelitian (Aprilia \& Darmawan, 2019; Murni \& Sabijono, 2018; Natalia et al., 2016; Sianipar, 2015) dimana dapat disebabkan karena bank yang semakin 
terdiversifikasi lebih beresiko dan bank-bank Indonesia diuntungkan oleh margin bunga tinggi (Hafidiyah \& Trinugroho, 2016). Diversifikasi pendapatan membutuhkan biaya yang lebih tinggi dengan kemungkinan mendapatkan imbal hasil yang tinggi pula ataupun sebaliknya tidak lebih tinggi dari biaya yang dikeluarkan sehingga memiliki resiko, dimana menurut (Sudana, 2009) dalam usaha meningkatkan nilai perusahaan, salah satu faktor yang dapat mempengaruhi yaitu bahwa investor umumnya menghindari resiko.

Secara statistik berdasarkan table 4 hubungan antara profitabilitas dan nilai perusahaan menunjukkan nilai beta 0,289 dengan $p$-value $<0,001$ dimana dengan kata lain profitabilitas memiliki pengaruh positif terhadap nilai perusahaan sehingga H3 diterima. Hasil ini konsisten dengan hasil penelitian (Aprilia \& Darmawan, 2019; Hasibuan et al., 2016; Simetris \& Darmawan, 2019). Profitabilitas menjadi salah satu faktor yang mempengaruhi dalam usaha meningkatkan nilai perusahaan (Sudana, 2009). Hal ini mencerminkan bahwa profitabilitas pada perbankan dapat menjadi sinyal baik bagi pasar untuk memberikan penilaian pasar yang tinggi sehingga dapat meningkatkan nilai perusahaan.

Dalam penelitian ini juga dilakukan uji mediasi dengan analisis jalur (Path Analysis) dengan menggunakan koefisien jalur c (dalam hal ini nilai beta). Jalur c dilihat dari kedua hubungan, yakni (1) hubungan langsung antara variabel independen terhadap dependen (direct effect) dan (2) hubungan tidak langsung (indirect effect) dengan melibatkan variabel mediasi (Baron \& Kenny, 1986). Apabila koefisien jalur c dari hasil estimatis kedua tetap signifikan dan tidak berubah $\left(c=c^{\prime}\right)$ maka hipotesis mediasi tidak didukung. Apabila koefisien jalur $c^{\prime}$ nilainya turun $\left(c^{\prime}<c\right)$ namun tetap signifikan, maka bentuk mediasi adalah mediasi sebagian (partial mediation). Apabila koefisien jalur $c^{\prime}$ hasilnya turun ( $c^{\prime}$ $<$ c) dan berubah menjadi tidak signifikan, maka bentuk mediasi adalah mediasi penuh (full mediation).

Berdasarkan hasil pada tabel 4 hubungan tidak langsung antara modal intelektual terhadap nilai perusahaan menunjukkan koefisien jalur c pada direct effect lebih besar dibanding indirect effect dengan nilai $p$-value tetap signifikan $<0,001$. Sehingga pengaruh modal intelektual terhadap nilai perusahaan melalui profitabilitas merupakan mediasi sebagian (partial mediation) sehingga H4 diterima. Hasil ini mendukung penelitian (Arief \& Yahya, 2014; Hadiwijaya \& Rohman, 2013; Sudibya \& Restuti, 2014) dimana profitabilitas mampu memediasi hubungan antara hubungan modal intelektual dan nilai perusahaan. Disamping itu pengaruh tidak langsung diversifikasi pendapatan terhadap nilai perusahaan pada table 7 menunjukkan nilai koefisien jalur c pada direct effect lebih besar dibanding pada indirect effect dengan nilai $p$-value 0,487 tetap tidak signifikan sehingga mediasi tidak didukung dan H5 ditolak. Hal ini mengindikasikan bahwa profitabilitas tidak mampu memediasi hubungan antara diversifikasi pendapatan dan nilai perusahaan. Adapun nilai $R$-Square hubunngan modal intelektual dan diversifikasi pendapatan terhadap nilai perusahaan melalui profitabilitas sebesar 19,5\%.

\section{KESIMPULAN}

Profitabilitas dipengaruhi oleh modal intelektual dan diversifikasi pendapatan pada perbankan di Indonesia. Modal intelektual memiliki pengaruh positif terhadap profitabilitas, 
dimana ketika modal intelektual meningkat diikuti dengan penigkatan profitabilitas perbankan maupun sebaliknya. Sementara itu diversifikasi pendapatan berpengaruh negatif terhadap profitabilitas perbankan. Hal ini dapat terjadi dikarenakan imbal hasil yang didapatkan dari proses diversifikasi tidak mampu menutupi biaya yang telah dikeluarkan. Modal intelektual berpengaruh positif terhadap nilai perusahaan, dimana peningkatan modal intelektual diikuti dengan peningkatan nilai perusahaan. Kemudian diversifikasi pendapatan ditemukan tidak berpengaruh terhadap nilai perusahaan dalam penelitian ini. Diversifikasi pendapatan yang tinggi lebih beresiko dan umumnya investor menghindari resiko. Nilai perusahaan juga dipengaruhi oleh profitabilitas. Peningkatan profitabilitas mampu menjadi sinyal positif bagi pasar untuk kemudian meningkatkan nilai perusahaan. Selain pengaruh langsung, ditemukan bahwa profitabilitas mampu memediasi hubungan antara modal intelektual dan nilai perusahaan dengan mediasi sebagian (partial mediation). Sedangkan profitabilitas belum mampu memediasi hubungan antara diversifikasi pendapatan dan nilai perusahaan pada perbankan.

Hasil penelitian ini dapat memberikan bukti empiris terkait pengaruh modal intelektual dan diversifikasi pendapatan terhadap nilai perusahaan dengan dimediasi oleh profitabilitas. Keterbatasan penelitian ini yaitu hasil berupa hubungan antar variabel pada seluruh perbankan yang menjadi sampel tanpa dikelompokan berdasarkan jenis bank, sehingga tidak diketahui secara detail pengaruh antar variabel pada jenis bank yang berbeda dan dalam penelitian ini profitabilitas hanya diproksikan dengan 2 proksi. Kemudian untuk peneliti selanjutnya dapat mengelompokkan bank dalam cluster sehingga dapat diketahui hubungan antar variabel pada masing-masing cluster yang berbeda, atau dapat menambah variabel maupun proksi pengukuran sesuai dengan teori dan bukti empiris yang ada.

\section{REFERENSI}

Aida, R. N., \& Rahmawati, E. V. I. (2015). Pengaruh Modal Intelektual dan Pengungkapannya Terhadap Nilai Perusahaan: Efek Intervening Kinerja Perusahaan. Jurnal Akuntansi Dan Investasi (JAI), 16(2), 96-109. https://doi.org/10.18196/JAI-2015.0035

Alipour, M. (2012). The effect of intellectual capital on firm performance : an investigation of Iran insurance companies. Measuring Business Excelent, 16(1), 53-66. https://doi. org/10.1108/13683041211204671

Amalia, R. F., \& Annisa, M. L. (2018). Analisis Hubungan Profitabilitas Dengan Modal Intelektual Perusahaan ( Studi Kasus Pada Perusahaan Pertambangan Sub Sektor Batubara di Bursa Efek Indonesia ). 3(2), 424-432.

Aprilia, A. D., \& Darmawan, A. (2019). Pengaruh Diversifikasi, Leverage dan Profitabilitas Terhadap Nilai Perusahaan. Jurnal Administrasi Bisnis (JAB), 73(2), 95-104.

Arief, M. I., \& Yahya, I. (2014). Pengaruh Modal Intelektual Terhadap Nilai Perusahaan dengan Kinerja Keuangan sebagai Variabel Intervening pada Perusahaan Perbankan yang Terdaftar di Bursa Efek Indonesia. Jurnal Telaah Dan Riset Akuntansi, 7(2), 142-155. 
Baron, R. M., \& Kenny, D. A. (1986). The Moderator-Mediator Variable Distinction in Social Psychological research: Copceptual, Strategic and Statistical Considerations. Journal of Personality and Social Psychology, 51, 1173-1182.

Buallay, A. (2019). Intellectual capital and performance of Islamic and conventional banking Empirical evidence from Gulf Cooperative Council countries. Journal of Management Development, 38(7), 518-537. https://doi.org/10.1108/JMD-01-2019-0020

Cahya, K. D., \& Riwoe, J. C. (2018). Pengaruh ROA dan ROE Terhadap Nilai Perusahaan dengan Sustainability Reporting sebagai Variabel Intervening pada Perusahaan yang Terdaftar di LQ 45. Journal of Accounting and Bussiness Studies, 3(1), 46-70.

Hadiwijaya, R. C., \& Rohman, A. (2013). Pengaruh Intellectual Capital Terhadap Nilai Perusahaan dengan Kinerja Keuangan sebagai Variabel Intervening. Diponegoro Journal of Accounting, 2(3), 1-7.

Hafidiyah, M. N., \& Trinugroho, I. (2016). Revenue Diversification, Performance, and Bank Risk: Evidence From Indonesia. Jurnal Dinamika Manajemen (JDM), 7(2), 139-148.

Hasibuan, V., Ar, M. D., \& Endang, N. G. W. (2016). Pengaruh Leverage dan Profitabilitas Terhadap Nilai Perusahaan ( Studi pada Perusahaan Property dan Real Estate yang Terdaftar di Bursa Efek Indonesia Periode Tahun 2012-2015 ). Jurnal Administrasi Bisnis (JAB), 39(1), 139-147.

Lepetit, L., Nys, E., Rous, P., \& Tarazi, A. (2008). Bank income structure and risk: An empirical analysis of European banks. Journal of Banking and Finance, 32(8), 1452-1467. https:// doi.org/10.1016/j.jbankfin.2007.12.002

Lestari. (2017). Pengaruh Intellectual Capital \& Kepemilikan Institusional Terhadap Nilai Perusahaan. Jurnal Dinamika Ekonomi Dan Bisnis, 14(1), 17-39.

Lukmawijaya, A., \& Suk, K. S. (2015). Bank Diversification Effect on Bank Performance and Risk Profile of Bank in Indonesia. DeReMa Jurnal Manajemen, 10(1), 74-84.

Luu, H. N., Nguyen, L. Q. T., Vu, Q. H., \& Tuan, L. Q. (2019). Income diversification and financial performance of commercial banks in Vietnam, Do experience and ownership structure matter? Review of Behavioral Finance. https://doi.org/10.1108/RBF-05-2019-0066

Murni, S., \& Sabijono, H. (2018). Peran Kinerja Keuangan dalam Menentuka Nilai Perusahaa. Jurnal Manajemen Bisnis Dan Inovasi, 5(2), 96-107.

Natalia, Kurniawan, M. R., \& Firsty, R. R. (2016). Bank Income Diversification from Stock Market Perspective: Evidence from ASEAN +3. Indonesian Capital Market Review, 8, 32-45.

Octavio, D. Q., \& Soesetio, Y. (2019). Intellectual capital and bank profitability: Evidence from conventional and Islamic bank in Indonesia. Jurnal Keuangan Dan Perbankan (JKP), 23(2), 191-205.

Putra, I. G. C. (2012). Pengaruh Modal Intelektual pada Nilai Perusahaan yang Go Public di Bursa Efek Indonesia. Jurnal Ilmiah Akuntansi Dan Humanika, 2(1), 1-22.

Salvatore, D. (2005). Ekonomi Manajerial dalam Perekonomian Global. Jakarta: Salemba Empat. 
Sari, I. A., Wiratno, A., \& Suyono, E. (2014). Pengaruh Strategi Diversifikasi dan Karakteristik PerusahaanTerhadap Kinerja Perusahaan. JAFFA, 02(1), 13-22.

Sawarjuwono, T., \& Kadir, A. P. (2003). Intellectual Capital: Perlakuan, Pengukuran, dan Pelaporan (Sebuah Library Research). Jurnal Akuntansi Dan Keuangan, 5(1), 35-57.

Setiawan, R., \& Pramika, M. (2019). Pengaruh Diversifikasi Pendapatan dan Bank Capital Buffer terhadap Kinerja dan Risiko Likuiditas pada Sektor Perbankan Syariah Indonesia. Jurnal Dinamika Ekonomi Dan Bisnis, 16(01).

Sharma, S., \& Anand, A. (2018). Income diversification and bank performance: evidence from BRICS nations. International Journal of Productivity and Performance Management, 67(9), 1625-1639. https://doi.org/10.1108/IJPPM-01-2018-0013

Sholihin, M., \& Ratmono, D. (2013). Analisis SEM-PLS dengan WarpPLS 3.0 Untuk Hubungan Non-Linier dalam Penelitian Sosial dan Bisnis. Yogyakarta: Penerbit ANDI.

Sianipar, A. S. (2015). Pengaruh Diversifikasi Pendapatan Terhadap Kinerja Bank. Jurnal Siasat Bisnis, 19(1), 27-35.

Simetris, S. A., \& Darmawan, A. (2019). Pengaruh Diversifikasi, Leverage dan Profitabilitas Terhadap Nilai Perusahaan (Studi pad Perusahaan Industri Barang Konsumsi yang Terdaftar di Bursa Efek Indonesia Tahun 2013-2017). Jurnal Administrasi Bisnis (JAB), 74(1), 39-47.

Subkhan, \& Citraningrum, D. P. (2010). Pengaruh Intellectual Capital Terhadap Kinerja Keuangan Perusahaan Perbankan Periode 2005-2007. Jurnal Dinamika Akuntansi, 2(1), 30-36.

Sudana, I. M. (2009). Manajemen Keuangan: Teori dan Praktik. Surabaya: Airlangga University Press.

Sudibya, D. C. N. A., \& Restuti, M. M. D. (2014). Pengaruh Modal Intelektual Terhadap Nilai Perusahaan dengan Kinerja Keuangan Sebagai Variabel Intervening. BENEFIT Jurnal Manajemen Dan Bisnis, 18(1), 14-29.

Sunarsih, Made, N., \& Mendra, N. P. Y. (2012). Pengaruh Modal Intelektual Terhadap Nilai Perusahaan dengan Kinerja Keuangan sebagai Variabel Intervening pada Perusahaan yang Terdaftar di Bursa Efek Indonesia. Simposium Nasional Akuntansi 15 (SNA 15). Banjarmasin.

Tran, D. B., \& Hong Vo, D. (2018). Should bankers be concerned with Intellectual capital? A study of the Thai banking sector. Journal of Intellectual Capital, 19(5), 897-914. https://doi.org/10.1108/JIC-12-2017-0185

Turkmen, S. Y., \& Yigit, I. (2012). Diversification in Banking and its Effect on Banks' Performance: Evidence from Turkey. American International Journal of Contemporary Research, 2(12), 111-119.

Werastuti, D. N. S. (2014). Model Moderasi dalam Hubungan antara Intellectual Capital Discloure, Nilai Perusahaan, dan Financial Performance. Jurnal Keuangan Dan Perbankan, 18(1), 14-28. 
Widiasari, F. W., \& Pangestuti, I. R. D. (2015). Pengaruh Struktur Pasar, Kompetisi, Diversifikasi,Kapitalisasi, Risiko Kredit, dan Size Terhadap Profitabilitas Bank. Diponegoro Journal of Management, 4(2), 1-12. Retrieved from http://ejournal-s1.undip.ac.id/index. $\mathrm{php} / \mathrm{dbr}$

Wijayani, D. R. (2017). Pengaruh Intellectual Capital Terhadap Kinerja Keuangan Perusahaan Publik di Indonesia. Jurnal Riset Akuntansi Dan Bisnis Airlangga (JRABA), 2(1), 97-116. 